\title{
Assessment of cardiac hemodynamic changes during pregnancy in normal and hypertensive women
}

\author{
Bushra Khairuddin Abdulqader, Zayd Kays Omer \\ Department of Medical Physiology, College of Medicine, University of Mosul, Mosul, Iraq. \\ Correspondence: Bushra Khairuddin Abdulqader. Boosh_k@yahoo.com.
}

(Ann Coll Med Mosul 2018; 40 (2): 9-17).

Received: $12^{\text {th }}$ Aug. 2018; Accepted: $18^{\text {th }}$ Nov. 2018.

\begin{abstract}
Background: The hypertensive disorders of pregnancy (HDP) are the most common complication of pregnancy and are major cause of maternal and perinatal morbidity and mortality. Hypertension in pregnancy complicates about $10 \%$ of all pregnancies worldwide.

Objective: This study aims to compare the hemodynamics of healthy pregnant women with hemodynamics of pregnant women with gestational hypertension $(\mathrm{GH})$ or preeclampsia $(\mathrm{PE})$.

Methods: A total of (120) women were included in this study; their ages range from (17 to 42) years; classified as follows: (60) normotensive pregnant women and (60) pregnant women with GH or PE. $2^{\text {nd }}$ group is subdivided into: (30) hypertensive pregnant women who take antihypertensive treatment (methyldopa) and (30) those without antihypertensive medications. All women subjected to echocardiographic examination by experience specialist.

Results: Compared with healthy pregnant women, untreated pregnant women with GH or PE were associated with increase mean arterial pressure (MAP) $(82.81 \pm 9.083 \mathrm{~mm} \mathrm{Hg}$ vs. $113.66 \pm 7.327 \mathrm{~mm} \mathrm{Hg}, \mathrm{p}<$ $0.001)$, increase total peripheral vascular resistance (TPR) (1379.01 \pm 425.65 dyn.sec.cm -5 vs. $1733.99 \pm$ 396.97 dyn.sec.cm-5, p<0.001), increased cardiac output (CO) $(5.01 \pm 1.100 \mathrm{~L} / \mathrm{min}$ vs. $5.55 \pm 1.42 \mathrm{~L} / \mathrm{min}, \mathrm{p}$ $=0.04)$, increased ejection fraction $(E F)(64.9 \pm 4.9 \%$ vs. $67.4 \pm 6.561 \%, p=0.04)$ and fractional shortening (FS) $(34.76 \pm 3.492 \%$ vs. $37.34 \pm 4.21 \%, p=0.003)$, increased left ventricular mass (LVM) (136.41 $\pm 29.22 \mathrm{gm}$ vs. $174.16 \pm 41.04 \mathrm{gm}, \mathrm{p}<0.001)$ and decreased ratio of peak velocity of early transmitral flow to late transmitral flow (E/A ratio) ( $1.39 \pm 0.166$ vs. $1.30 \pm 0.19, p=0.02)$.

The hypertensive pregnant patients treated with methyldopa; compared to non-treated group; showed a significant decreased in MAP $(99.91 \pm 13.874 \mathrm{~mm} \mathrm{Hg}$ vs. $113.66 \pm 7.325 \mathrm{~mm} \mathrm{Hg}, \mathrm{p}<0.001$, decreased TPR (1534.58 \pm 349.47 dyn.sec.cm -5 vs. $1733.99 \pm 396.97$ dyn.sec.cm $-5, p=0.04)$, decreased EF $(63.7 \pm 4.621 \%$ vs. $67.4 \pm 6.561 \%, p=0.014)$, decreased LVM $(153.087 \pm 33.778 \mathrm{gm}$ vs. $174.16 \pm 41.04 \mathrm{gm}, \mathrm{p}=0.03)$ and significant increase in $E / A$ ratio ( $1.444 \pm 0.262$ vs. $1.306 \pm 0.190, p=0.02)$.

Conclusion: Pregnant women with PE or GH have evidence of hemodynamic changes that justify routine echocardiographic assessment even in the absence of cardiac symptoms.
\end{abstract}

Keywords: Echocardiography, hypertension, pregnancy.

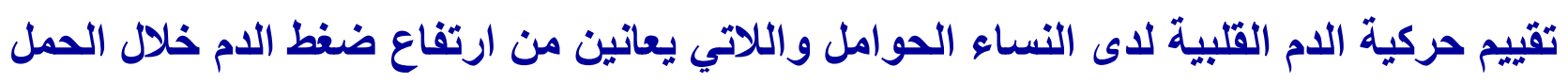

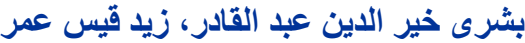

$$
\begin{aligned}
& \text { فرع الفسلجة الطبية، كلية الطب، جامعة الموصل، الموصل، العراق }
\end{aligned}
$$

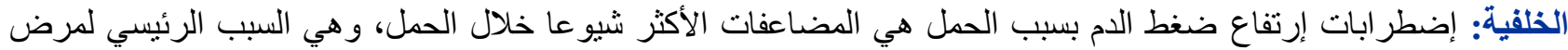

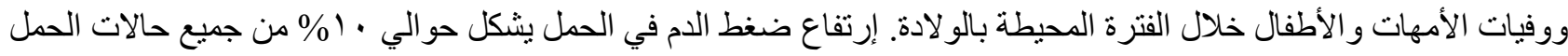

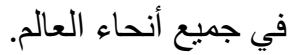


الهُف: هذه الدر اسة تهدف الى مقارنة حركية الدم للنساء الحو امل الأصحاء مع حركية الدم للنساء الحوامل المصابات بإرتفاع

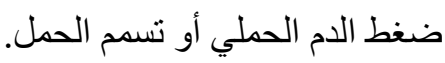

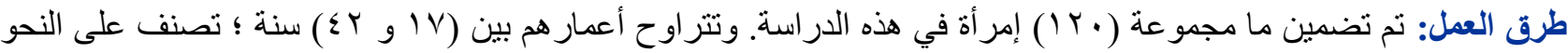

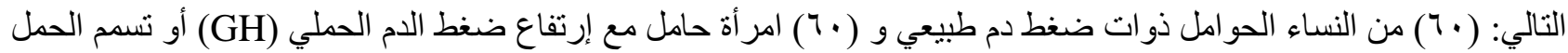

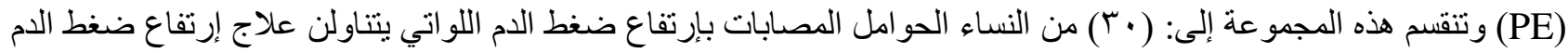

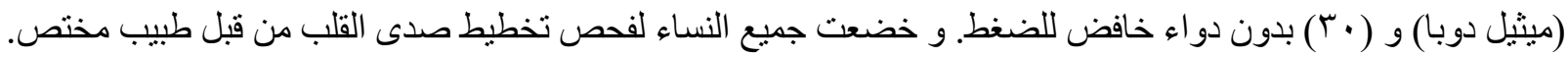

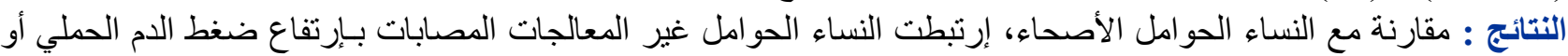

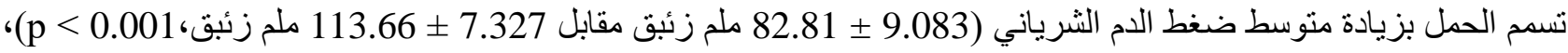

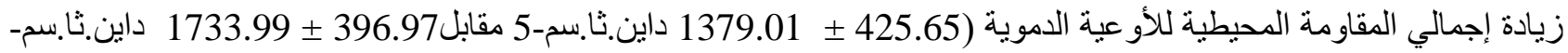

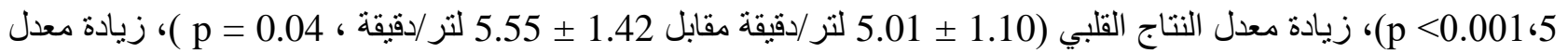

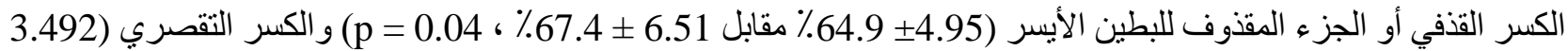

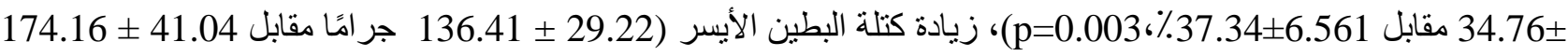

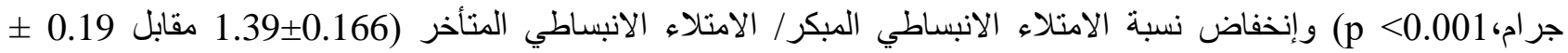
. $(\mathrm{p}=0.02 \cdot 1.30$

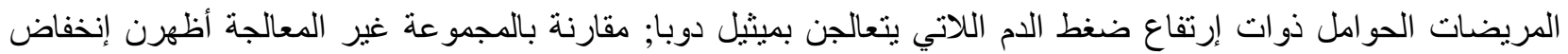

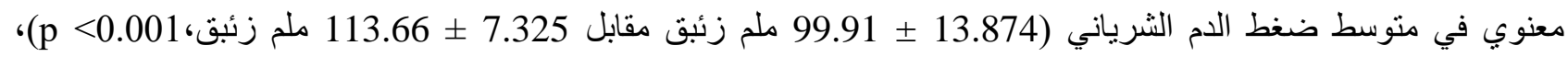

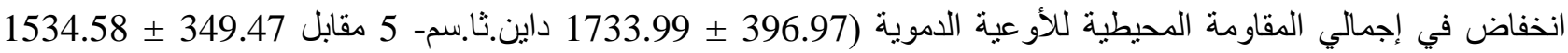

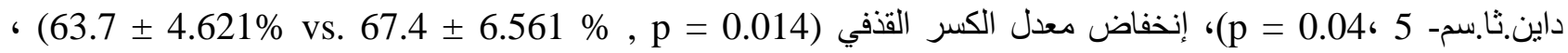

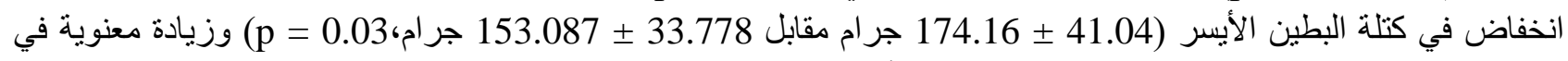

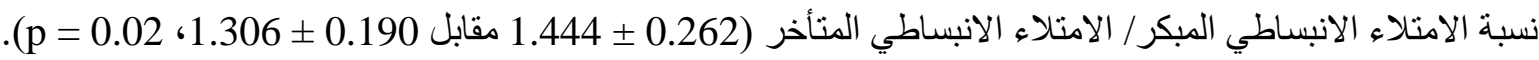

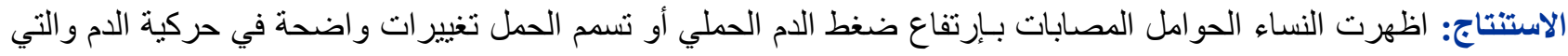

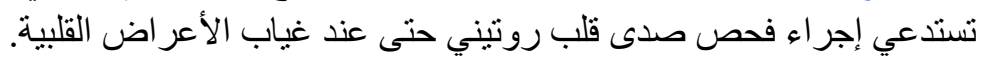

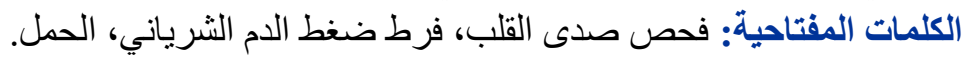

\section{INTRODUCTION}

$T$ he hypertensive disorders of pregnancy (HDP) are the most common complication of pregnancy and are major cause of maternal and perinatal morbidity and mortality ${ }^{1}$. Hypertension (HT) in pregnancy complicates about $10 \%$ of all pregnancies worldwide ${ }^{2}$. General classification of HDP (according to ACOG):

- Gestational or transient hypertension.

- Preeclampsia or eclampsia.

- Chronic hypertension.

- Chronic hypertension with superimposed preeclampsia ${ }^{2}$.

Gestational hypertension (GH); is hypertension (systolic blood pressure $\geq 140 \mathrm{mmHg}$ and / or diastolic blood pressure $\geq 90 \mathrm{mmHg}$, on two occasions, taken at least 4 hours apart) without proteinuria or other signs of organ dysfunction, first appears after 20 weeks' gestation and resolves by 12 weeks postpartum ${ }^{3}$. From a management point of view, the final diagnosis can only be done after the pregnancy has been finished so, the assumption must be made that any woman who develops hypertension must be considered to be at risk of maternal and fetal complications ${ }^{4}$.

Preeclampsia (PE) is defined as new onset of hypertension (systolic blood pressure $\geq 140 \mathrm{mmHg}$ and / or diastolic blood pressure $\geq 90 \mathrm{mmHg}$, on two occasions, taken at least 4 hours apart ) in the $2^{\text {nd }}$ half of gestation in a woman with a previously normal blood pressure and may remain as late as $4-6$ weeks postpartum, often accompanies by proteinuria or associated with other signs and symptoms including headache, visual disturbance, epigastric pain and the rapidly developing edema $^{2,3}$.

Transthoracic echocardiography is often considered as the reference standard for cardiovascular (CV) system diagnosis, monitoring and research uses. It is valid, precise and 
reproducible measurement device providing information not only about cardiac output but also about systolic and diastolic function, and structural and functional information ${ }^{5}$. It is the most widely used imaging modality for assessment of $\mathrm{CV}$ function during pregnancy ${ }^{6}$.

\section{MATERIALS AND METHODS}

This is a case - control study, performed between November 2017 till April 2018 in the Echocardiography Unit at Al-Salam Teaching Hospital and Ibn altheer Teaching Hospital in Mosul city.

\section{Subjects}

After institutional ethics approval and informed consent, a total of 120 women were included in this study; their ages range from 17 to 42 years; classified as follows:

- group I, (60) normotensive pregnant women.

- group II, (60) pregnant women with GH or PE. This group is subdivided into: (30) hypertensive pregnant women who take antihypertensive treatment (methyldopa) and (30) those without antihypertensive medications.

The following criteria of exclusion were considered: Significant medical and surgical illness, structural heart disease and accidental echo finding of valvular heart disease and congenital heart disease, smoker, moderate and severe anemia, diabetes mellitus, essential hypertension, drugs that increase blood pressure as $\beta_{2}$ agonists or taking other antihypertensive medication (other than methyldopa), less than 20 weeks of gestation or uncertain dates, multiple pregnancy, fetal anomalies, uterine and placental abnormalities, antepartum hemorrhage and starting labour.

After medical history and clinical examination, standing height and body weight were measured for each subject at the time of the study, and those values were used to calculate body mass index (BMI) and body surface area (BSA), arterial pulse rate was measured by palpating radial artery, electrocardiograph (ECG) was done and blood pressure were obtained from the brachial artery using a calibrated mercury sphygmomanometer in the sitting position after the women had rested for at least 10 minutes with arm supported at the level of the heart, recording the diastolic value as Korotkoff $\mathrm{V}$ was used according to the American Heart Association. The mean arterial pressure (MAP) was calculated from: diastolic pressure + $1 / 3$ pulse pressure while total peripheral resistance (TPR) was calculated from: MAP $\times 80 / C O$ dynes.sec/ $\mathrm{cm}^{5}$.

\section{Echocardiography}

With the subjects resting in the left lateral decubitus position, standard two- dimensional, Mmode and Doppler transthoracic echocardiographic examinations were performed by experience echocardiographer according to ASE/EAE guidelines ${ }^{7,8}$, using Sono ACE X6, Medison/Chorea and Logiq S6, GE Healthcare/USA machines. M-mode study was done at the level of mitral valve leaflet tips with $\mathrm{M}$ mode line perpendicular to the long axis of the heart in the parasternal long axis view to measure: Left ventricular internal dimension at diastole (LVIDd) and systole (LVIDs). Interventricular septal thickness at diastole (IVSd) and posterior left ventricular wall thickness during diastole (PWTd). From which the following parameters were obtained: End diastolic volume (EDV) and end systolic volume (ESV) were calculated by the machine using the Teichholz formula and the difference between them is stroke volume (SV), cardiac output (CO) was obtained by multiplying $\mathrm{SV}$ by $\mathrm{HR}$ per minute. Ejection Fraction $(\mathrm{EF})=$ (EDV - ESV) / EDV, and Fractional Shortening $(F S)=($ LVIDd - LVIDs $) /($ LVIDd $) \times 100$ were also obtained. Left ventricular mass (LVM) was calculated using the following formula: LVM (gram) $=0.8 \times\left[1.04(\text { LVIDd }+ \text { PWTd }+ \text { IVSd })^{3}-\right.$ LVIDd $\left.^{3}\right]$ +0.6 . LV mass index $\left(\mathrm{g} / \mathrm{m}^{2}\right)$ was obtained by dividing LV mass on the subject's BSA. Transmitral flow pattern (peak $E$ wave velocity, peak $A$ wave velocity and $E / A$ ratio) were measured; using pulsed wave Doppler; obtained from the apical four chamber view.

\section{Statistical Analysis}

All data were analyzed using the Statistical Package for Social Science (SPSS) software version 21 and were expressed in terms of mean \pm standard deviation. Unpaired independent t-test was used to compare between normotensive 
pregnant and non-treated pregnant with $\mathrm{GH}$ and $\mathrm{PE}$, and between treated and non-treated pregnants with $\mathrm{GH}$ and $\mathrm{PE}$. Chi $\left(\mathrm{X}^{2}\right)$ test was used to test the association between categorical variables. Pearson's test; to test the correlation between BMI, LVM and MAP; was used. In all tests, $\mathrm{P}$ - value $<0.05$ was considered to be statistically significant.

\section{Results}

Maternal distributions according to age, parity and BMI

Regarding maternal age, a significant association exits with PE or $\mathrm{GH}$. (40\%) of the hypertensive pregnant women were above (35 years) which represent the highest percent, (36.7\%) of hypertensive pregnant women aged between (2635 years), the lowest percent $(23.3 \%)$ was among those aged between (17 -25 years).

$\mathrm{BMI}$ has significant association to $\mathrm{PE}$ or $\mathrm{GH}$. Only $6(10 \%)$ of hypertensive prgnants had normal weight, while 20 (33.3\%) were obese class I, $(26.7 \%)$ were obese class II, (23.3\%) were overweight and $(6.7 \%)$ were obese class III. (Table 1).

A significant association between parity and women with PE or $\mathrm{GH}$. A (53.3\%) of hypertensive pregnant women were grand multiparous, $(26.7 \%)$ of them were multiparous and $(20 \%)$ of women were primiparous.

\section{Comparison between normotensive pregnant women and untreated PE or GH}

Compared with normotensive group, untreated $\mathrm{PE}$ or GH group was significantly older $(28.03 \pm 6.48$ years vs. $31.67 \pm 8.691$ years), higher BMI (28.12 $\pm 6.41 \mathrm{~kg} / \mathrm{m}^{2}$ vs. $\left.33 \pm 5.67 \mathrm{~kg} / \mathrm{m}^{2}\right)$, higher BSA $\left(1.733 \pm 0.19\right.$ vs. $\left.1.89 \pm 0.191 \mathrm{~m}^{2}\right)$, (Table 2).

MAP $(113.66 \pm 7.327 \mathrm{~mm} \mathrm{Hg}$ vs. $82.81 \pm 9.083$ $\mathrm{mm} \mathrm{Hg})$, TPR $\left(1733.99 \pm 396.97\right.$ dyne.s. $\mathrm{cm}^{-5}$ vs. $1379.01 \pm 425.65$ dyne.s.cm $\left.{ }^{-5}\right)$, SV $(63.75 \pm 15.95$ $\mathrm{ml}$ vs. $55.18 \pm 12.285 \mathrm{ml})$ and $\mathrm{CO}(5.55 \pm 1.42 \mathrm{~L} / \mathrm{min}$ vs. $5.01 \pm 1.100 \mathrm{~L} / \mathrm{min}$ ) were significantly increased in untreated group compared to normotensive pregnant group (Table 3).

There were no significant change in LV dimensions and volumes. IVSd $(1.03 \pm 0.18 \mathrm{~cm})$ and PWTd $(1.14 \pm 0.135 \mathrm{~cm})$ are markedly higher in untreated $\mathrm{PE}$ or $\mathrm{GH}$ than that of normotensive pregnant group $(0.918 \pm 0.162 \mathrm{~cm}, 1 \pm 0.139 \mathrm{~cm}$, respectively) and so, LVM and LVMI were higher in the untreated group compared to normotensive pregnant women $(174.16 \pm 41.04 \mathrm{gm}, 92.25 \pm 20.02$ $\mathrm{gm} / \mathrm{m}^{2}$ vs. $136.41 \pm 29.22 \mathrm{gm}, 78.79 \pm 14.569 \mathrm{gm} / \mathrm{m}^{2}$, respectively). EF $(67.4 \pm 6.561 \%$ vs. $64.9 \pm 4.955 \%)$ and FS $(37.34 \pm 4.21 \%$ vs. $34.76 \pm 3.492 \%)$ were also significantly higher in untreated PE or $\mathrm{GH}$ than that of normotensive pregnant group (Table 4).

A mitral wave velocity is significantly increase $(67.5 \pm 10 \mathrm{~cm} / \mathrm{sec}$ vs $59.57 \pm 11.22 \mathrm{~cm} / \mathrm{sec})$ with significant decrease in E/A ratio ( $1.3 \pm 0.19$ vs 1.394 \pm 0.166 ) were noticed in the untreated group (Table 5).

Table 1. Age, BMl and parity distributions among pregnant women.

\begin{tabular}{|c|c|c|c|}
\hline Parameter & Category & $\begin{array}{c}\text { Normotensive } \\
\text { pregnant }\end{array}$ & PE or GH \\
\hline \multirow[t]{3}{*}{ Age } & $17-25$ & $(36.7 \%) 22$ & $\begin{array}{c}(23.3 \%) \\
14\end{array}$ \\
\hline & $26-35$ & $(53.3 \%) 32$ & $\begin{array}{c}(36.7 \%) \\
22\end{array}$ \\
\hline & $\geq 36$ & $(10 \%) 6$ & $(40 \%) 24$ \\
\hline \multicolumn{2}{|l|}{ Total } & $(100 \%) 60$ & $(100 \%) 60$ \\
\hline \multicolumn{4}{|c|}{ chi $=15.364 \quad p$-value $=0.002$} \\
\hline \multirow[t]{5}{*}{ BMI } & $\begin{array}{l}\text { Normal } \\
\text { weight } \\
18.5-24.9\end{array}$ & $(40 \%) 24$ & $(10 \%) 6$ \\
\hline & $\begin{array}{l}\text { Over weight } \\
25-29.9\end{array}$ & $(30 \%) 18$ & $\begin{array}{c}(23.3 \%) \\
14\end{array}$ \\
\hline & $\begin{array}{l}\text { Obese class } \\
\text { | } \\
30-34.9\end{array}$ & $(6.7 \%) 4$ & $\begin{array}{c}(33.3 \%) \\
20\end{array}$ \\
\hline & $\begin{array}{l}\text { Obese class } \\
\text { II } \\
35-39.9\end{array}$ & $(20 \%) 12$ & $\begin{array}{c}(26.7 \%) \\
16\end{array}$ \\
\hline & $\begin{array}{l}\text { Obese class } \\
\text { III } \\
>40\end{array}$ & $(3.3 \%) 2$ & $(6.7 \%) 4$ \\
\hline Total & & $(100 \%) 60$ & $(100 \%) 60$ \\
\hline chi=13.581 & \multicolumn{3}{|l|}{$p$-value $=0.003$} \\
\hline \multirow[t]{3}{*}{ Parity } & 0 & $(23.3 \%) 14$ & $(20 \%) 12$ \\
\hline & $1-4$ & $(46.7 \%) 28$ & $\begin{array}{c}(26.7 \%) \\
16\end{array}$ \\
\hline & $\geq 5$ & $(30 \%) 18$ & $\begin{array}{c}(53.3 \%) \\
32\end{array}$ \\
\hline Total & & (100\%) 60 & $(100 \%) 60$ \\
\hline chi=16.203 & $p$-value $=0.00$ & & \\
\hline
\end{tabular}


Table 2. Comparison of baseline characteristics between normotensive pregnant women and untreated PE or $\mathrm{GH}$.

\begin{tabular}{lccc}
\hline Parameter & $\begin{array}{c}\text { Normotensive } \\
\text { pregnant } \\
(\mathrm{n}=60)\end{array}$ & $\begin{array}{c}\text { Untreated } \\
\text { PE or GH } \\
(\mathrm{n}=30)\end{array}$ & $\begin{array}{c}\text { P- } \\
\text { value }\end{array}$ \\
\hline $\begin{array}{l}\text { Age (years) } \\
\text { Parity }\end{array}$ & $3 \pm 2.03 \pm 6.481$ & $31.67 \pm 8.691$ & 0.02 \\
$\begin{array}{l}\text { Gestational } \\
\text { age (GA) } \\
\text { (weeks) }\end{array}$ & $27 \pm 5.386$ & $3.8 \pm 3.158$ & NS \\
$\begin{array}{l}\text { BMI } \\
\left(\mathrm{kg} / \mathrm{m}^{2}\right)\end{array}$ & $28.12 \pm 6.413$ & $33 \pm 5.827$ & $\mathrm{NS}$ \\
$\mathrm{BSA}\left(\mathrm{m}^{2}\right)$ & $1.73 \pm 0.190$ & $1.89 \pm 0.191$ & $<0.001$ \\
\hline
\end{tabular}

Table 3. Comparison of hemodynamic characteristics between normotensive pregnant women and untreated $\mathrm{PE}$ or $\mathrm{GH}$.

\begin{tabular}{|c|c|c|c|}
\hline Parameter & $\begin{array}{l}\text { Normotensive } \\
\text { pregnant } \\
(\mathrm{n}=60)\end{array}$ & $\begin{array}{l}\text { Untreated } \\
\text { PE or GH } \\
(n=30)\end{array}$ & $\begin{array}{l}P \\
\text { value }\end{array}$ \\
\hline $\begin{array}{l}\text { MAP (mm } \\
\mathrm{Hg})\end{array}$ & $82.81 \pm 9.083$ & $\begin{array}{c}113.66 \pm \\
7.327\end{array}$ & $<0.001$ \\
\hline PR (bpm) & $92.56 \pm 8.495$ & $\begin{array}{c}88.53 \pm \\
13.505\end{array}$ & NS \\
\hline $\begin{array}{l}\text { TPR } \\
\left(\text { dyne.s.cm }{ }^{5}\right)\end{array}$ & $1379.01 \pm 425.65$ & $\begin{array}{c}1733.99 \pm \\
396.97\end{array}$ & $<0.001$ \\
\hline SV (ml) & $55.18 \pm 12.285$ & $\begin{array}{c}63.75 \pm \\
15.95\end{array}$ & $<0.01$ \\
\hline CO (L/min) & $5.01 \pm 1.100$ & $\begin{array}{c}5.55 \pm \\
1.42\end{array}$ & 0.04 \\
\hline
\end{tabular}

Table 4. Comparison of echocardiographic parameters between normotensive pregnant women and untreated PE or GH.

\begin{tabular}{|c|c|c|c|}
\hline Parameter & $\begin{array}{l}\text { Normotensi } \\
\text { ve pregnant } \\
(n=60)\end{array}$ & $\begin{array}{l}\text { Untreated PE } \\
\text { or } \mathrm{GH}(n=30)\end{array}$ & $\begin{array}{l}P \\
\text { value }\end{array}$ \\
\hline LVIDd $(\mathrm{cm})$ & $4.32 \pm 0.396$ & $4.47 \pm 0.499$ & NS \\
\hline EDV ( I) & $85.186 \pm 17.826$ & $92.96 \pm 24.39$ & NS \\
\hline LVIDs (cm) & $2.79 \pm 0.302$ & $2.8 \pm 0.414$ & NS \\
\hline ESV (ml) & $29.75 \pm 7.749$ & $32.46 \pm 14.526$ & NS \\
\hline EF ( \%) & $64.9 \pm 4.9$ & $67.4 \pm 6.561$ & 0.04 \\
\hline FS ( \%) & $34.76 \pm 3.492$ & $37.34 \pm 4.21$ & 0.003 \\
\hline IVSd (cm) & $0.918 \pm 0.162$ & $1.03 \pm 0.18$ & 0.003 \\
\hline PWTd (cm) & $1 \pm 0.139$ & $1.14 \pm 0.135$ & $<0.001$ \\
\hline LVM (g) & $136.41 \pm 29.22$ & $174.16 \pm 41.04$ & $<0.001$ \\
\hline $\operatorname{LVMI}\left(\mathrm{g} / \mathrm{m}^{2}\right)$ & $78.79 \pm 14.569$ & $92.25 \pm 20.02$ & $<0.001$ \\
\hline
\end{tabular}

Table 5. Comparison of Mitral flow velocities between normotensive pregnant women and untreated PE or GH.

\begin{tabular}{|c|c|c|c|}
\hline Parameter & $\begin{array}{l}\text { Normotensive } \\
\text { pregnant } \\
(\mathrm{n}=60)\end{array}$ & $\begin{array}{l}\text { Untreated } \\
\text { PE or GH } \\
(n=30)\end{array}$ & P-value \\
\hline $\begin{array}{l}\text { E wave } \\
\text { velocity } \\
\text { (cm/sec) }\end{array}$ & $83.97 \pm 18.228$ & $88.5 \pm 15.761$ & NS \\
\hline $\begin{array}{l}\text { A wave } \\
\text { velocity } \\
\text { (cm/sec) }\end{array}$ & $59.57 \pm 11.221$ & $67.5 \pm 10$ & 0.001 \\
\hline E / A ratio & $1.39 \pm 0.166$ & $1.30 \pm 0.19$ & 0.02 \\
\hline
\end{tabular}

\section{Comparison between treated and untreated PE or GH}

Within the hypertensive group, comparisons were made between the treated and untreated patients (Table 6,7). Regarding general characteristics, mean age, parity, GA and BMI were similar in both groups. In untreated hypertensive women, systolic BP $(150.33 \pm 10.580 \mathrm{~mm} \mathrm{Hg})$, diastolic BP (95.33 \pm $10.080 \mathrm{~mm} \mathrm{Hg})$ and MAP $(113.66 \pm 7.325 \mathrm{~mm} \mathrm{Hg})$ were significantly higher than treated group were systolic BP was $(129.166 \pm 16.870 \mathrm{~mm} \mathrm{Hg})$, diastolic BP $(85.33 \pm 13.450 \mathrm{~mm} \mathrm{Hg})$ and MAP was $(99.91 \pm 13.874 \mathrm{~mm} \mathrm{Hg}), \quad$ TPR is significantly decreased in the treated group (1733.99 \pm 396.97 vs. $1534.58 \pm 349.47$ dyn.sec. $\left.\mathrm{cm}^{-5}\right)$. No significant changes in $\mathrm{CO}$ and SV between the groups.

LVM was higher in untreated group compared to treated one $(174.16 \pm 41.04$ vs. $153.087 \pm 33.778$, respectively). A significant decrease in transmitral A velocity in treated group as compared to untreated one $(59.533 \pm 9.964$ vs $67.527 \pm 10$, respectively) and in E/A ratio (1.444 \pm 0.262 vs. $1.306 \pm 0.190$, respectively) with no significant change in transmitral $E$ velocity.

Table 6. Comparison of baseline characteristics between treated and non-treated PE or $\mathrm{GH}$.

\begin{tabular}{llll}
\hline Parameter & $\begin{array}{l}\text { Non- } \\
\text { treated } \\
\text { patients } \\
(\mathrm{n}=30)\end{array}$ & $\begin{array}{l}\text { Treated } \\
\text { patients } \\
(\mathrm{n}=30)\end{array}$ & P-value \\
\hline $\begin{array}{l}\text { Age } \\
\text { (years) }\end{array}$ & $31.67 \pm 8.691$ & $32.8 \pm 8.002$ & $\mathrm{NS}$ \\
\hline $\begin{array}{l}\text { Parity } \\
\text { GA }\end{array}$ & $3.8 \pm 3.158$ & $4.8 \pm 3.585$ & $\mathrm{NS}$ \\
$\begin{array}{l}\text { weeks) } \\
\text { BMI } \\
\left(\mathrm{kg} / \mathrm{m}^{2}\right)\end{array}$ & $33.8 \pm 5.827$ & $30.87 \pm 6.516$ & $\mathrm{NS}$ \\
\hline $\mathrm{BSA}\left(\mathrm{m}^{2}\right)$ & $1.89 \pm 0.191$ & $1.84 \pm 0.138$ & $\mathrm{NS}$ \\
\hline
\end{tabular}




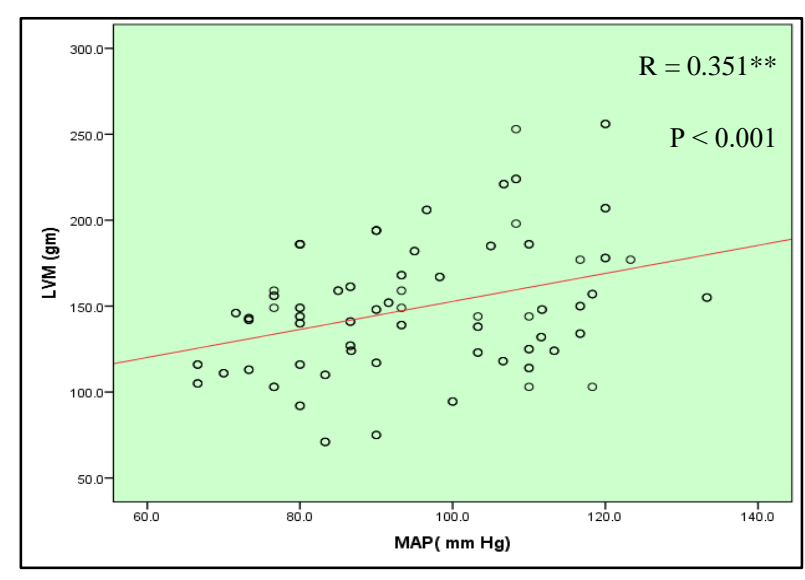

Figure 1. Correlation between LVM and MAP.

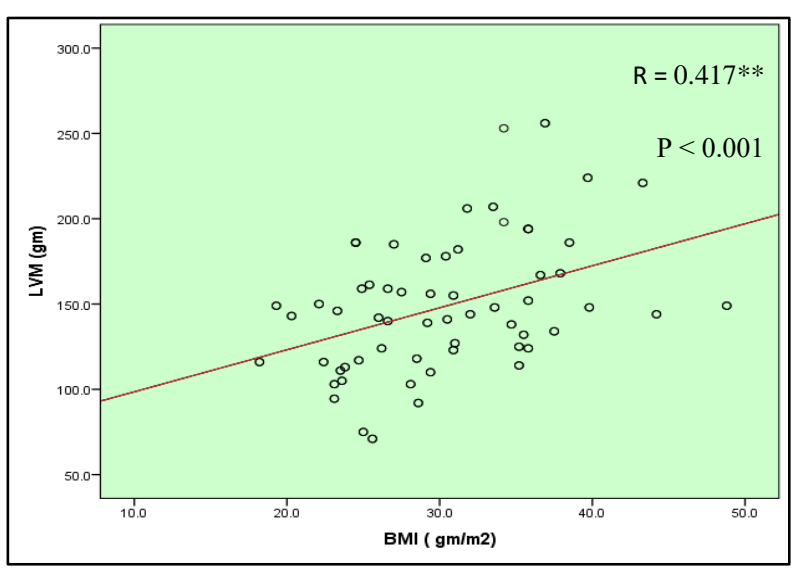

Figure 2. Correlation between LVM and BMI.

Table 7. Comparison of hemodynamic and echocardiographic parameters between treated and nontreated PE or $\mathrm{GH}$.

\begin{tabular}{|c|c|c|c|}
\hline Parameter & $\begin{array}{l}\text { Non-treated } \\
\text { patients } \\
(n=30)\end{array}$ & $\begin{array}{l}\text { Treated } \\
\text { patients }(n=30)\end{array}$ & $\begin{array}{l}\mathrm{P}- \\
\text { value }\end{array}$ \\
\hline $\begin{array}{l}\text { Systolic BP } \\
(\mathrm{mm} \mathrm{Hg})\end{array}$ & $\begin{array}{c}150.33 \pm \\
10.580\end{array}$ & $129.166 \pm 16.870$ & $<0.001$ \\
\hline $\begin{array}{l}\text { Diastolic } \\
\mathrm{BP}(\mathrm{mmHg})\end{array}$ & $95.33 \pm 10.080$ & $85.33 \pm 13.450$ & $<0.001$ \\
\hline $\begin{array}{l}\text { Mean arterial } \\
\text { pressure } \\
(\mathrm{mmHg})\end{array}$ & $113.66 \pm 7.325$ & $99.91 \pm 13.874$ & $<0.001$ \\
\hline $\begin{array}{l}\text { Pulse rate } \\
\text { (beats per } \\
\text { min ) }\end{array}$ & $88.53 \pm 13.505$ & $90.93 \pm 6.658$ & NS \\
\hline $\mathrm{SV}(\mathrm{ml})$ & $63.75 \pm 15.95$ & $60.23 \pm 13.372$ & NS \\
\hline $\mathrm{CO}(\mathrm{L} / \mathrm{min})$ & $5.55 \pm 1.42$ & $5.40 \pm 1.141$ & NS \\
\hline $\begin{array}{l}\text { TPR } \\
\left(\text { dyn.sec. } \mathrm{cm}^{-5} \text { ) }\right.\end{array}$ & $\begin{array}{c}1733.99 \pm \\
396.97\end{array}$ & $1534.58 \pm 349.47$ & 0.04 \\
\hline EF \% & $67.4 \pm 6.561$ & $63.7 \pm 4.621$ & 0.014 \\
\hline LVM ( gm ) & $174.16 \pm 41.04$ & $153.087 \pm 33.778$ & 0.03 \\
\hline $\begin{array}{l}\text { E wave } \\
\text { velocity }\end{array}$ & $88.51 \pm 15.761$ & $85.51 \pm 14.196$ & NS \\
\hline $\begin{array}{l}\text { A wave } \\
\text { velocity }\end{array}$ & $67.527 \pm 10$ & $59.533 \pm 9.964$ & 0.003 \\
\hline E / A ratio & $1.306 \pm 0.190$ & $1.444 \pm 0.262$ & 0.02 \\
\hline
\end{tabular}

\section{DISCUSSION}

Hypertensive disorders of pregnancy, including GH and $\mathrm{PE}$, remain the main cause of maternal morbidity and mortality in developing and developed countries. The hemodynamics of PE and $\mathrm{GH}$ are complex ${ }^{9}$, and studies on left ventricular structures and function are not only scarce, but also controversial on many topics ${ }^{10}$ There is a growing body of literature concerning the pathophysiology of preeclampsia which may be a heterogeneous disease with diverse hemodynamic subsets ${ }^{9}$. PE has been described variously as:

- a state of abnormally high $\mathrm{CO}$ and low systemic vascular resistance (SVR) .

- a state of abnormally low CO and high SVR.

- a state of abnormally high $\mathrm{CO}$ and high $\mathrm{SVR}^{11}$.

This study showed that pregnant women with $\mathrm{GH}$ or $\mathrm{PE}$ were characterized by high $\mathrm{CO}$ and high TPR state and normal physiological changes in left ventricular structures and function were exaggerated in this group.

$\mathrm{GH}$ and $\mathrm{PE}$ have common risk factors ${ }^{12}$. By comparing age wise distribution between normal and hypertensive women, age has been found to have a significant effect on the incidence of HDP, with maternal age $\geq 35$ years is important risk factor. About more than $1 / 3^{\text {rd }}(40 \%)$ of the patient were above 35 years which also reported by Alrubaee, (2006) ${ }^{13}$ and sheraz et al., (2006) who reported that $\mathrm{PE}$ is more common in patient younger than 21 years and older than 35 years, Duckitt et al., (2005) suggest that the increase placental villous reaction in women older than 30 years may contribute to PE development ${ }^{14}$.

Not only primiparous are at high risk for developing PE but also the multiparous women, similar report was found by Alrubaee, $(2006)^{13}$.

High BMI is an important risk factor for PE and $\mathrm{GH}{ }^{13,15}$ that was confirmed by this study. The explanation may be an increased level of Creactive protein, which is involved in the inflammatory process of HDP, is found in obese patients. In addition, some facts suggest that obesity augmented endothelial role and promoted systemic inflammatory reaction that linked to atherosclerosis which play a part in pregnancy induced hypertension ${ }^{16}$. 
Heart rate was not significantly changed in this study that is agree with others ${ }^{17-19}$.

TPR was high in the hypertensive; as reported by other studies ${ }^{10,18,19}$; because systemic maternal arteries in women with PE show endothelial dysfunction that is characterized by endothelial injury, decreased dilatory responses, and imbalance in the bioavailability of endotheliumderived vasoactive substances ${ }^{20}$.

There were no significant change in LV dimensions and volumes. These changes agree with other studies ${ }^{10,17,21-25}$.

$\mathrm{CO}$ was significantly higher in untreated hypertensive group and this compatible with the proposed hyperdynamic model that is also reported by other studies ${ }^{10,18,25}$.

The value of the finding a high $\mathrm{CO}$ in the group of untreated women lies not in the reality that because of the higher BMI in this group, but rather the enhancement in inotropy that was found in this group. In the usual situation, if someone is much larger than another person, then their $\mathrm{CO}$ is usually higher. The explanation for this, is that their heart is larger, their EDV are larger, consequently their SV are larger however, their FS and EF remain similar to the smaller individual. Dennis et al (2010) had demonstrated that the reason for the increased $\mathrm{CO}$ in women with untreated PE is an increase in inotropy not an increase in LV EDV ${ }^{5,18}$.

LV EF is considered the most commonly reported measure of global LV function ${ }^{26}$. Significant increase observed in EF and FS between untreated hypertensive pregnant and normotensive pregnant groups as reported by Dennis et al (2010) ${ }^{5,18}$ and Kim et al (2016) ${ }^{17}$; and this could be explained by increase cardiac inotropy and LVM, while others ${ }^{21-25}$ suggested a non-significant changes. LV EF and FS are sensitive to altered loading condition, and this could explain this differences.

Mitral E (early) velocity was increased, this proposed that transmitral pressure gradient during early passive filling is greater and reflects alterations in passive cardiac muscles compliance in the hypertrophic ventricle, this non-significant difference in $E$ wave velocity is found also in other studies $^{21,22}$. A more(significant) increase in A (atrial) mitral velocity; and this is compatible with other results ${ }^{21,22,25}$; and decrease in E/A ratio as agree with others ${ }^{21,22,25}$ was found in untreated hypertensive; give an opinion to the more role of atrial contraction in hypertrophied ventricular muscles of these pregnant.

IVSd, PWTd and thus the LVM and LVMI were significantly increased in hypertensive pregnant women that is agree with most studies ${ }^{10,18,21-24}$. (Figure 1). The heart must adapt its wall thickness to this raise in pressure load in spite of the short lasting overload. The explanation of this is that, when the heart faces a hemodynamic load, it can work by following ways to compensate:

- Using Frank - Starling mechanism to increase cross bridges formation.

- Increase muscle mass to tolerate the extra load.

- Recruit neurohormonal mechanism as sympathetic or renin-angiotensin aldosterone system to augment contractility ${ }^{27}$.

$\mathrm{BMI}$ is a significant factor for increased LVM, and there is a significant positive correlation between them as shown in Figure 2.

\section{While treated vs. untreated PE or GH}

As MAP depends on both $\mathrm{CO}$ and TPR, a reduction in BP could be achieved either by decreasing $\mathrm{CO}$ and/or TPR. Antihypertensive drugs benefit from these three mechanisms ${ }^{28}$.

All of our treated patients were taking methyldopa only, a centrally acting antihypertensive drug that stimulate alpha adrenergic receptors in the brain stem inhibiting efferent sympathetic tone ${ }^{28}$, decreasing BP and TPR without significant changes on $\mathrm{CO}, \mathrm{PR}$ and $\mathrm{SV}^{29}$ and this is compatible with the results of this study.

Also treated women showed a reduction of LVM compared to untreated group and this effect of methyldopa confirmed clinically by other studies ${ }^{30}$. This is either due to hemodynamical effect by decreasing TPR or non-hemodynamically by a direct effect of methyldopa on decreasing cardiac muscle protein synthesis as shown by Pegram et al., (2000) who mentioned that a short time period (three weeks in their study) treatment with methyldopa resulted in a reduction of LVM of spontaneously hypertensive rats ${ }^{31}$.

A significant decrease in mitral $A$ wave velocity and increase in $E / A$ ratio reflects improvement in the LV compliance and thus diastolic performance in those treating with methyldopa ${ }^{32}$. 


\section{CONCLUSION}

- Transthoracic echocardiography considered a good non-invasive method for evaluation of hemodynamic during pregnancy.

- Monitoring of BP alone is not enough to identify risk of CV complications. Routine echo assessment for hypertensive women is needed to predict the risk for complications even before the appearance of symptoms.

- Women with PE or GH have increased CO, increased inotropy and increased TPR.

- Patients with PE or GH are associated with increased LVM. Heavy maternal weight may exaggerate this increase.

- Short lasting pressure overload in a previously young and healthy heart is able to make changes in LV.

- Women with PE or GH treated with methyldopa showed a significant decreased in MAP and TPR with improvement in the LV compliance and thus diastolic performance.

\section{REFERENCES}

1.MacDonell KL, Moutquin JM and Sebbag I. Diagnosis, Evaluation, and Management of the Hypertensive Disorders of Pregnancy: Executive Summery. Journal of Obstetrics and Gynaecology Canada. 2014 ;36(5): 416438.

2.Task Force on Hypertension in Pregnancy. Hypertension in Pregnancy. The American College of Obstetricians and Gynecologists 2013.

3.Hacker NF, Gambone JC and Hobel CJ. Hacker\& Moore's: Essentials of Obstetrics \& Gynecology. $6^{\text {th }}$ ed. Elsevier. 2016; p 183-193.

4.Symonds IM and Arulkumaran SS. Essentials Obstetrics and Gynaecology. $5^{\text {th }}$ ed. Elsevier.2013. p 90. 5.Dennis AT. Cardiac Function in Women with Preeclampsia. Ph D Thesis, published. Department of Pharmacology, Faculty of Medicine, Dentistry and health Science. University of Melbourne. Australia. 2010

6.Ducas RA, Elliott JE, Melnyk SF, et al. Cardiovascular magnetic resonance in pregnancy: Insights from the cardiac hemodynamic imaging and remodeling in pregnancy (CHIRP) study. Journal of Cardiovascular Magnetics Resonance.2014; 16: 1.

7.Gottdiener JS, Bednarz J, Devereux R, Gardin J, et al. American Society of Echocardiography Recommendations for Use of Echocardiography in Clinical Trials. Journal of the American Society of Echocardiography. 2004; 17:1086-1119.

8.Galderisi M, Henein MY, D'Hooge $J$, et al. Recommendation of the European Association of Echocardiography: How to use Echo-Doppler in clinical trials: different modalities for different purposes. European Journal of Echocardiography.2011; (12):339353.
9.Otto, CM. The Practice of Clinical Echocardiography. $4^{\text {th }}$ ed. Philadelphia; Saunders Elsevier. 2012. p664-671. 10.Rizwana $S$ and Nandita $M$. Echocardiographic Assessment of Cardiovascular Haemodynamics in Preeclampsia. The Journal of Obstetrics and Gynecology of India. 2011;61(5):519-522.

11.Decherney $A H$, Nathan L, Laufer $N$, et.al. Current Diagnosis \& Treatment Obstetrics \& Gynecology. $11^{\text {th }}$ ed. McGraw-Hill Companies.2011; p 459-464.

12.Shen $M$, Smith GN, Rodger $M$, et al. Comparison of risk factors and outcomes of gestational hypertension and pre-eclampsia. PLoS One.2017; 12(4): e0175914.

13.Alrubaee MA. RISK FACTORS AND LABOR OUTCOME IN PAROUS WOMEN WITH PREECLAMPSIA. Medical Journal of Basrah University. 2006(24), No.1\&2:23-28.

14.Kumari N, Dash $\mathrm{K}$ and Singh R. Relationship between Maternal Age and Preeclampsia. Journal of Dental and Medical Science.2016;15(12):55-57.

15. Hogan JL, Anglim B, O'Dwyer, et al. Body mass index and hypertensive disorders of pregnancy. Pregnancy Hypertension.2012;2(1):28-31.

16.Kazemian E, Sotoudeh G, Dorosty-Motlagh AR, et al. Maternal Obesity and Energy Intake as a Risk Factors of Pregnancy-induced Hypertension among Iranian Women. Journal of Health, Population and Nutrition. 2014;32(3): 486-493.

17.Kim M, Seo J, Cho K, et al. Echocardiographic Assessment of Structural and Hemodynamic Changes in Hypertension Related Pregnancy. Journal of Cardiovascular Ultrasound. 2016;24(1): 28-34.

18.Dennis AT, Castro J, Carr C, et al. Haemodynamics in untreated Pre-eclampsia. Anaesthesia. 2012; 67:1105-1118.

19.Melchiorre K, Sutherland GS, Baltabaeva A, et al. Maternal Cardiac Dysfunction and Remodeling in Women with Preeclampsia at Term. Hypertension. 2011; 57:85-93.

20.Goulopoulou S. Maternal Vascular Physiology in Preeclampsia. Hypertension. 2017; 70:1066-1073.

21.Cho KI, Kim DS, Kim TI, et al. Echocardiographic Assessment of LV Geometric Pattern and Function in Pregnancy-Induced Hypertension. Korean Circulation Journal. 2005; 35:718-724.

22.Cho KI, Kim S, Shin M, et al. Impact of Gestational Hypertension on Left Ventricular Function and Geometric Pattern. Circulation Journal. 2011; 75:11701176.

23.Blanco MV, Grosso O, Bellido CA, et al. Left Ventricular Geometry in Pregnancy-Induced Hypertension. American Journal of Hypertension. 2000; 13:226-230.

24.Kahramonovich AF. Peculiarities of cardiac hemodynamic in pregnant women with mild preeclampsia. European Science Review .2015;5-6:5658.

25.Vlahovic-Stipac A, Stankic V, Popovic ZB, et al. Left Ventricular Function in Gestational Hypertension: Serial Echocardiographic Study. American Journal of Hypertension. 2010;23(1):85-91.

26.Marwick TH, Gillebert TC, Aurigemma G, et al. Recommendations on the Use of Echocardiography in Adult Hypertension: A Report from the European Association of Cardiovascular Imaging (EACVI) and the 
American Society of Echocardiography. Journal of the American Society of Echocardiography. 2015;28(7):727754.

27.Lorell $\mathrm{BH}$ and Carabello BA. Left ventricular hypertrophy: pathogenesis, detection, and prognosis. Circulation. 2000; 102:470-479.

28.Zwieten PA and Greenlee WJ. Antihypertensive Drugs. Harwood academic publishers. 1997.p:464-466.

29.Eskes TK and Finster M. Drug Therapy During Pregnancy. Butterworths. 1985.p 60-61.

30.Fouad FM, Nakashima Y, Tarazi RC and Salcedo

EE. Revearsal of left ventricular hypertrophy in hypertensive patients treated with methyldopa. Lack association with blood pressure control. American Journal of Cardiology. 1982;49(40):795-801.
31.Pegram B, Ishize S, Frohlich ED. Effect of methyldopa, clonidine, and hydralazine on cardiac mass and hemodynamics in Wistar Kyoto and spontaneously hypertensive rats: An historical account and some follow-up. Cardiovascular Research. 2000;45(1):79-81. 32.Giles TD, Sander GE, Thomas MG and Quiroz AC. Alpha-adrenergic mechanisms in the pathophysiology of left ventricular heart failure: an analysis of their role in systolic and diastolic dysfunction. Journal of Molecular and Cellular Cardiology.1986; 5:33-43. 